\title{
Quality of Educational Service at the Faculty of Social Sciences and Humanities of a Public University
}

\author{
Lidia Luz Cruz Neyrai \\ Enrique Guzmán y Valle National University of Education, Lima, Peru
}

Elías Saturnino Toledo Espinozai

Enrique Guzmán y Valle National University of Education, Lima, Peru

\author{
Arturo Jaime Mendonza Ramíreziii@ \\ Enrique Guzmán y Valle National University of Education, Lima, Peru
}

\begin{abstract}
The quality of the educational service is one of the factors that is present as the objective of every university institution and, therefore, the quality of training of professionals in Peru, both in its face-to-face and remote modality. The objective of the research was to determine the association of expectation and perception of the quality of educational service provided by the National University of Education. The selected exhibition consisted of 189 students from the Faculty of Social Sciences and Humanities. They responded to the survey based on the SERVQUAL model that measures the expectation of students of a university of excellence and the perception of educational service that is offered by the institution. The association between the two variables was evaluated through Spearman's Rho correlation. The results demonstrate a weak association of student expectation and perception variables at a significance level of 0.05 . Likewise, these results are extended to the security dimension, in contrast to the other dimensions such as tangibility, responsiveness, empathy and reliability. This means that the gaps $(P-E)$ that are the differences between perception $(P)$ and Expectations (E) suggest that improvement plans must be implemented to obtain the quality of educational service that students demand.
\end{abstract}

Keywords

SERVQUAL. Quality of educational service. Gaps.

\section{Qualidade do serviço educativo na Faculdade de Ciências Sociais e Humanas}

\author{
de uma universidade pública
}

\begin{abstract}
Resumo
A qualidade do serviço educacional é um dos fatores que está presente como objetivo de toda instituição universitária e, portanto, a qualidade da formação dos profissionais no Peru, tanto na modalidade presencial como remota. O objetivo da pesquisa foi verificar a associação entre expectativa e percepção da qualidade do serviço educacional prestado pela Universidade Nacional de Educação. A exposição selecionada foi composta por 189 alunos da Faculdade de Ciências Sociais e Humanas. Eles responderam à pesquisa com base no modelo SERVQUAL que mede a expectativa dos alunos de uma universidade de excelência e a percepção do serviço educacional que é oferecido pela instituição. A associação entre as duas variáveis foi avaliada por meio da correlação Rho de Spearman.
\end{abstract}

Educ. Form., Fortaleza, v. 6, n. 3, e5293, set./dez. 2021

DOI: https://doi.org/10.25053/redufor.v6i2.5293

https://revistas.uece.br/index.php/redufor/index 
Os resultados demonstram uma fraca associação das variáveis de expectativa e percepção dos alunos a um nível de significância de 0,05. Da mesma forma, esses resultados se estendem para a dimensão segurança, em contraposição às demais dimensões como tangibilidade, capacidade de resposta, empatia e confiabilidade. Isso significa que os gaps (P-E) que são as diferenças entre percepção $(P)$ e Expectativas $(E)$ sugerem que planos de melhoria devem ser implementados para se obter a qualidade do serviço educacional que os alunos demandam.

\title{
Palavras-chave
}

SERVQUAL. Qualidade do serviço educacional. Lacuna.

\section{Calidad del servicio educativo en la Facultad de Ciencias Sociales y Humanidades de una universidad pública}

\begin{abstract}
Resumen
La calidad del servicio educativo es uno de los factores que está presente como objetivo de toda institución universitaria y, por tanto, la calidad de la formación de los profesionales en el Perú, tanto en su modalidad presencial como a distancia. El objetivo de la investigación fue determinar la asociación de expectativa y percepción de la calidad del servicio educativo brindado por la Universidad Nacional de Educación. La muestra seleccionada estuvo compuesta por 189 estudiantes de la Facultad de Ciencias Sociales y Humanidades. Respondieron a la encuesta con base en el modelo SERVQUAL que mide la expectativa de los estudiantes de una universidad de excelencia y la percepción del servicio educativo que ofrece la institución. La asociación entre las dos variables se evaluó mediante la correlación Rho de Spearman. Los resultados demuestran una asociación débil de las expectativas de los estudiantes y las variables de percepción a un nivel de significancia de 0.05. Asimismo, estos resultados se extienden a la dimensión de seguridad, en contraste con las otras dimensiones como la tangibilidad, la capacidad de respuesta, la empatía y la confiabilidad. Esto significa que las brechas (P-E) que son las diferencias entre percepción $(P)$ y Expectativas $(E)$ sugieren que se deben implementar planes de mejora para obtener la calidad del servicio educativo que demandan los estudiantes.
\end{abstract}

\section{Palabras clave}

SERVQUAL. Calidad del servicio educativo. Brechas.

\section{Introduction}

2020 has been a year of challenges for Peru, particularly in health, the economy and education. Therefore as is public knowledge, the declaration of the State of Health Emergency issued by Supreme Decree 008-2020-SA; establishing COVID 19 prevention and propagation control measures; resulted in the promulgation of Legislative Decree 1495 to ensure the continuity and quality of the provision of the educational service. This document provided that educational institutions may develop their therapy programmers,

Educ. Form., Fortaleza, v. 6, n. 3, e5293, set./dez. 2021

DOI: https://doi.org/10.25053/redufor.v6i2.5293

https://revistas.uece.br/index.php/redufor/index 
under semi-presence or remote mode, through the use of virtual learning environments, until the educational service is restored in person. Consequently, the remote teaching modality is not exempt from the requirement of quality standards in the sector.

Within the framework of quality, one of the main players in the university community are students. For this reason, the perception of university quality through satisfaction is one of the dynamics that has been considered in many of the national and international university institutions. Satisfaction results are used for decision-making, such as the formulation of improvement plans.

One of the main functions of an educational institution, particularly university, is to meet the needs of the student, as posed by the Models of Total Quality Management. It is therefore conducive to identifying what these needs might be that require attention, in order to assess and take appropriate actions to achieve quality improvement. In this sense, an instrument should be sought that collects information on educational quality, through student satisfaction with the main interest of determining the positive and negative aspects in the undergraduate context. This generates indicators that can help the school receive feedback when evaluated to help you optimize the service it offers.

Candelas et al. (2013) made a measurement of the satisfaction of students of a Mexican higher education center, using as a data collection tool the questionnaire called Student University Satisfaction (SEU), which was applied to a sample of 163 students of the industrial engineering career, identifying six dimensions: academic aspect, administrative aspect, empathy, academic offer, complementary aspects and environment, which account for $68 \%$ of the total variance.

De Castro et al. (2012) state that students should be considered as their clients who need to be served and institutions demonstrate their quality. So, many of the accreditation models; as the case of ISO 9001:2008, which states that the organization must ensure the student's requirements through their perception.

Ahmad and Almas (2013) reported that studies on student opinion have increased in recent decades as part of policy-making diagnostics in higher education. One of the highlights has been students' satisfaction with their teachers. These evaluations have been considered for administrative decisions such as promotion, permanence and training for their own improvement.

Educ. Form., Fortaleza, v. 6, n. 3, e5293, set./dez. 2021 
Fonseca (2019) y Fantin (2017) have pointed out the need to implement actions to improve educational quality and student satisfaction, such as training future teachers in the practice of pedagogical use of information and communication technologies and the integrating technologies in the learning process, respectively.

Vergara and Quesada (2011) conducted research on two variables such as quality of service and student satisfaction, for which the student population of the Faculty of Economics of the University of Cartagena was counted. His data were analyzed to propose a mathematical model consisting of structural equations.

Correia and Miranda (2012) reported that Bologna's institutional diagnostic process has allowed a great concern for the management of the quality of the educational service offered to institutions of the higher level, mainly universities in Spain. The quality of educational service at the higher level focuses not only on the teaching processlearning, teacher-student relationship, but also includes the quality of academic services such as that provided in libraries, projection or social responsibility systems, welfare services, mentoring, follow-up of their graduates and departmental secretariats.

In Peru, Yenque de Dios and Ráez Guevara (1999) carried out research taking as an analysis unit the Universidad Nacional Mayor de San Marcos to measure educational quality, taking as variable the level of satisfaction of their students. The purpose of the research was to describe which methods are appropriate to improve the quality of the services provided by the university by referring to academics. The methodology was based on observation and surveys of all actors in the university community such as managers, students, teachers and administrative staff.

Bullón (2007) researched student satisfaction of educational quality in 56 engineering students from the Pontifical Catholic University of Peru, to whom they applied a survey to measure satisfaction. An acceptable level of satisfaction was found for students in the Mechanical Engineering career, while quite satisfied for students of the Electronic, Industrial and Civil engineering career. Factors such as the skills developed in his training, as part of his egress profile, were of greater satisfaction than those regarding the university's consideration of its socioeconomic level.

Naldos and Rosas (2018) reported that students of the Service Management program, at the University of Piura, have a better perception of the security dimension in the quality of educational service, measured through the SERVQUAL survey. 


\section{Material and methods}

The intentional sample consisted of 189 students from the entrance promotions from 2016 to 2019 from the career of the Faculty of Social Science and Humanities at the Enrique Guzmán y Valle National University of Education, as shown in Table 1.

Table 1 - Sample of students from the Faculty of Social Sciences and Humanities

\begin{tabular}{ccc}
\hline Sections & Frequency & Percentage \\
\hline H1 & 9 & 4,8 \\
H2 & 3 & 1,6 \\
H7 & 26 & 13,8 \\
HF & 12 & 6,3 \\
S1 & 53 & 28,0 \\
S2 & 31 & 16,4 \\
S3 & 28 & 14,8 \\
S4 & 27 & 14,3 \\
Total & 189 & 100,0 \\
\hline
\end{tabular}

Source: Own elaboration.

Parasuraman, Zeithaml and Berry (1988) surveys, called SERVQUAL (Service Quality), were used to collect information from variables expectation and perception of quality, with 22 items. The Likert scale was entirely at odds with totally according to values from 1 to 5 respectively. It should be noted that this instrument was adapted to the conditions of the educational service remotely.

The reliability of the instrument was estimated through the Cronbach coefficient. The calculation of this coefficient determines that if its value is close to the unit, it is a reliable instrument that makes stable and consistent measurements. The surveys in this study reached a Cronbach coefficient of 0.974 and 0.957 for expectation and perception, respectively, so it can be indicated that the instrument is reliable.

\section{Results}

The responses of the evaluations of the items of greatest interest were subjected to statistical analysis to determine the degree of association or correlation between the variables.

Educ. Form., Fortaleza, v. 6, n. 3, e5293, set./dez. 2021

DOI: https://doi.org/10.25053/redufor.v6i2.5293

https://revistas.uece.br/index.php/redufor/index 


\subsection{Expectation of the quality of educational service}

Table 2 shows the results of the application of the questionnaire on expectations of the quality of education service and the averages of the 22 items in that questionnaire. As noted, the lowest average is obtained by item 1 which corresponds to the excellent universities have virtual classrooms, which are always available when you want to access it and this criterion has an average rating of 4.67 . That is, $77.14 \%$ agree with this requirement for a quality university.

Item 2 also states that excellent universities should have virtual classrooms as a space that contributes efficiently to learning. This reaches an average rating of 4.73 , with $94 \%$ of students considering this criterion to be expected at a quality university.

Table 2 - Results of expectations of the quality of educational service

\begin{tabular}{|c|c|c|c|}
\hline & & Item/Description & Average \\
\hline \multirow{4}{*}{ 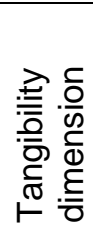 } & 1. & $\begin{array}{l}\text { A quality university has virtual classroom always available when you want to } \\
\text { access it. }\end{array}$ & 4.78 \\
\hline & 2. & The virtual classroom should be a space that contributes efficiently to learning. & 4.73 \\
\hline & 3. & The intranet must allow enrollment, without any difficulty. & 4.69 \\
\hline & & $\begin{array}{l}\text { The intranet should allow you to view the academic record and process the } \\
\text { certificates. }\end{array}$ & 4.67 \\
\hline \multirow{5}{*}{ 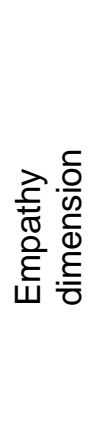 } & 5. & $\begin{array}{l}\text { At a quality university there is always technical support in online work moments } \\
\text { that I can easily contact via e-mail/phone / WhatsApp. }\end{array}$ & 4.65 \\
\hline & & $\begin{array}{l}\text { Teachers should be interested in always attending to me/ teaching me in a } \\
\text { willing and friendly manner. }\end{array}$ & 4.71 \\
\hline & $\begin{array}{l}7 . \\
8 .\end{array}$ & $\begin{array}{l}\text { Teachers should properly guide to perform activities left in the virtual classroom. } \\
\text { At a quality university, teachers acquit consultations in a timely and efficient manner. }\end{array}$ & $\begin{array}{l}4.56 \\
4.57\end{array}$ \\
\hline & 9. & $\begin{array}{l}\text { Teachers should strive to maintain good weather in virtual classroom sessions, } \\
\text { so that we feel at ease in it. }\end{array}$ & 4.58 \\
\hline & & $\begin{array}{l}\text { The quality university is concerned with providing various extracurricular } \\
\text { activities that contribute to my personal development (virtual events related to } \\
\text { the health, recreational or general culture emergency). }\end{array}$ & 4.37 \\
\hline \multirow{7}{*}{ 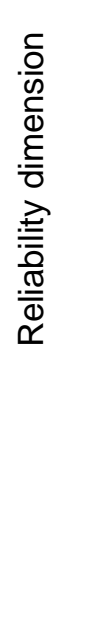 } & & $\begin{array}{l}\text { The Quality University cares about meeting the need for its students to have the } \\
\text { means to receive virtual classes (Laptop, Tablet, cell phone, internet, etc.). }\end{array}$ & 4.66 \\
\hline & & $\begin{array}{l}\text { Teachers comply with delivering the grades and solve the exams the week } \\
\text { after they have been applied. }\end{array}$ & 4.57 \\
\hline & & $\begin{array}{l}\text { When teachers promise to do something (assessments, assignments, } \\
\text { exhibitions, problem solving, videos, etc.) in a given time, they do it correctly } \\
\text { from the first time. }\end{array}$ & 4.46 \\
\hline & & $\begin{array}{l}\text { The quality university meets the agreed hours (synchronous sessions) for } \\
\text { teaching-related activities (class hours, exams and workshops). }\end{array}$ & 4.66 \\
\hline & & $\begin{array}{l}\text { The quality university complies with providing information for virtual classroom } \\
\text { use, as well as its activities and resources through a manual, video, or } \\
\text { introductory class. }\end{array}$ & 4.46 \\
\hline & & $\begin{array}{l}\text { The quality university complies with training or training in the use of the virtual } \\
\text { library and other resources. }\end{array}$ & 4.50 \\
\hline & & $\begin{array}{l}\text { At a quality university, students can quickly contact the university's various } \\
\text { offices through the directory, available on the intranet or its platform. }\end{array}$ & 4.53 \\
\hline
\end{tabular}

Educ. Form., Fortaleza, v. 6, n. 3, e5293, set./dez. 2021

DOI: https://doi.org/10.25053/redufor.v6i2.5293

https://revistas.uece.br/index.php/redufor/index 
Table 2 - Results of expectations of the quality of educational service

(conclusion)

$$
\text { Item/Description }
$$

18. At a quality university If an application/consultation is made, the university responds in the time promised.

9. The intranet and virtual classroom work correctly and error-free.

20. At a quality university there is sufficient confidence and security in the exams applied through the virtual classroom.

21. A quality university relies on teaching provided by teachers, postgraduate studies, work experience and professional updates.

22. At a quality university, teachers efficiently use synchronous sessions across different platforms. Average

Source: Own elaboration.

\subsection{Perception of the Quality of Educational Service}

Table 3 shows the average ratings to the items in the educational service perception questionnaire provided by the Enrique Guzmán y Valle National University of Education, applied to students of the Faculty of Social Sciences and Humanities The average obtained in item 7 corresponds to the highest rating, which is 4.73 . That is, $94 \%$ perceive that their teachers guide them appropriately to carry out the assigned activities in the virtual classroom.

Then item 6 with an average of 3.97, where $79 \%$ of students believe that UNE teachers are interested in always attending/teaching in a willing and friendly manner. However, the lowest value obtained is item 19, with an average of 2.57 . That is, $51 \%$ of students perceive that the intranet and virtual classroom are functioning correctly and errorfree, followed by item 19 where $53 \%$ of students perceive that if they make a query or application, UNE responds within the time it promised to do so.

Table 3 - Results of perceptions of the quality of educational service

\begin{tabular}{|c|c|c|}
\hline & Item/Description & Average \\
\hline \multirow{6}{*}{ 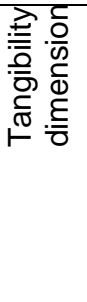 } & 1. The Virtual Classroom is always available when you want to access it. & 3.48 \\
\hline & 2. The virtual classroom is a space that contributes efficiently to my learnings. & 3.94 \\
\hline & 3. The intranet allows me to make the registration, without any difficulty. & 3.36 \\
\hline & 4. The intranet allows me to view the academic record and process the certificates. & 3.48 \\
\hline & $\begin{array}{l}\text { 5. There is technical support in online work moments that I can easily contact via } \\
\text { e-mail/phone/WhatsApp. }\end{array}$ & 3.41 \\
\hline & $\begin{array}{l}\text { 6. UNE teachers are interested in always caring for/teaching me in a willing and } \\
\text { friendly manner. }\end{array}$ & 3.97 \\
\hline \multirow{3}{*}{ 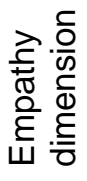 } & 7. Teachers guide us appropriately to carry out the activities left in the virtual classroom. & 4.13 \\
\hline & 8. Teachers absolve consultations in a timely and efficient manner. & 3.74 \\
\hline & $\begin{array}{l}\text { 9. Teachers strive to maintain good weather in virtual classroom sessions, so } \\
\text { that we feel at ease in it. }\end{array}$ & 3.79 \\
\hline
\end{tabular}

Educ. Form., Fortaleza, v. 6, n. 3, e5293, set./dez. 2021

DOI: https://doi.org/10.25053/redufor.v6i2.5293

https://revistas.uece.br/index.php/redufor/index 
Table 3 - Results of perceptions of the quality of educational service

Item/Description

(conclusion)

\begin{tabular}{|c|c|c|c|}
\hline & & Item/Description & Average \\
\hline \multirow{4}{*}{ 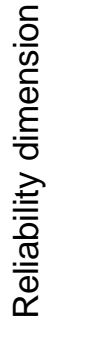 } & 10. & $\begin{array}{l}\text { UNE is concerned with providing me with various extracurricular activities that } \\
\text { contribute to my personal development (virtual events related to the health, } \\
\text { recreational or general culture emergency). }\end{array}$ & 2.79 \\
\hline & 11. & $\begin{array}{l}\text { UNE is concerned with meeting the need for its students to have the means to } \\
\text { receive virtual classes (Laptop, Tablet, cell phone, internet, etc.). }\end{array}$ & 2.97 \\
\hline & 12. & $\begin{array}{l}\text { Teachers comply with handing us notes and resolve exams the week after they } \\
\text { have been applied. }\end{array}$ & 3.29 \\
\hline & 13. & $\begin{array}{l}\text { When teachers promise to do something (assessments, assignments, exhibitions, } \\
\text { problem solving, videos, etc.) in a given time, they do it correctly from the first time. }\end{array}$ & 3.66 \\
\hline \multirow{5}{*}{ 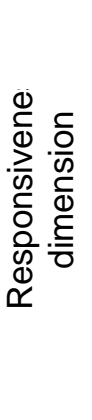 } & 14. & $\begin{array}{l}\text { UNE complies with agreed hours (synchronous sessions) for teaching-related } \\
\text { activities (class hours, exams and workshops). }\end{array}$ & 3.71 \\
\hline & 15. & $\begin{array}{l}\text { UNE complies with providing information for virtual classroom use, as well as its } \\
\text { activities and resources through an introductory manual, video, or class. }\end{array}$ & 3.81 \\
\hline & 16. & $\begin{array}{l}\text { UNE complies with training or training in the use of the virtual library and other } \\
\text { resources. }\end{array}$ & 2.87 \\
\hline & 17. & $\begin{array}{l}\text { Students can quickly contact the various UNE offices through the directory, } \\
\text { available on the UNE intranet or platform. }\end{array}$ & 2.69 \\
\hline & 18. & $\begin{array}{l}\text { If you make arequest/consultation at UNE, it is answered in the time I was } \\
\text { promised. }\end{array}$ & 2.66 \\
\hline \multirow{4}{*}{ 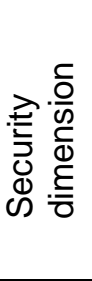 } & 19. & The intranet and virtual classroom work correctly and error-free. & 2.57 \\
\hline & 20. & $\begin{array}{l}\text { There is sufficient confidence and security in the exams applied through the } \\
\text { virtual classroom. }\end{array}$ & 2.95 \\
\hline & 21. & $\begin{array}{l}\text { I rely on the teaching provided by UNE teachers, according to their postgraduate } \\
\text { studies, work experience and professional updates. }\end{array}$ & 3.74 \\
\hline & 22. & $\begin{array}{l}\text { Teachers efficiently use synchronous sessions through Google Meet. } \\
\text { Average }\end{array}$ & $\begin{array}{l}3.83 \\
3.40\end{array}$ \\
\hline
\end{tabular}

Source: Own elaboration.

The SERVQUAL model establishes an analysis of the gaps in the quality factors of educational service. The following formula is used for the calculation of gaps: Gap - Perception (P) - Expectation (E). In Table 4, we can see the results of gaps or gaps (Perception Expectation), being the dimension responsiveness that corresponds to the university has the right and willingness to help users and provide a fast service. In addition, that it should provide facilities for students to find job opportunities has the biggest gap (-1.49). The security dimension corresponds to the knowledge and attention shown by employees and their skills to gain credibility and confidence in the student has as a gap the value -1.45 .

Table 4-Gaps depending on the size of the quality of the educational service

\begin{tabular}{lrcc}
\hline Dimension & Perception $(\mathrm{P})$ & Expectation $(\mathrm{E})$ & Gap (P-E) \\
\hline Tangibles & 3.56 & 4.72 & -1.16 \\
Empathy & 3.54 & 4.58 & -1.04 \\
Reliability & 3.55 & 4.56 & -1.01 \\
Responsiveness & 3.01 & 4.50 & -1.49 \\
Security & 3.27 & 4.71 & -1.44 \\
Global & 3.40 & 4.61 & -1.21 \\
\hline
\end{tabular}

Source: Own elaboration.

\subsection{Correlation of expectations and perceptions of the quality of educational service}

Educ. Form., Fortaleza, v. 6, n. 3, e5293, set./dez. 2021

DOI: https://doi.org/10.25053/redufor.v6i2.5293

https://revistas.uece.br/index.php/redufor/index 
Variable expectations and perceptions were correlated with the purpose of knowing whether the perception of the service provided, which means its satisfaction, goes hand in hand with the expectation of the quality of a university of excellence.

For this, you have two statistical hypotheses to be contrasted:

$H_{o r}$ : There is no association between variables (Equivalent to saying: there is no association between variable expectations and perceptions of students regarding the quality of educational service).

$\mathrm{H}_{\mathrm{A}}$ : If there is an association (if there is a relationship; there is dependence between those variables).

Applying Spearmann's correlation test shows that there is no correlation, 0.05 significance level. Expectations and perceptions of the quality of educational service provided to students of Social Sciences and Humanities of the National University of Education Enrique Guzmán y Valle (UNE), during the 2020-I semester, is weakly associated with a significance level of 0.05 .

\section{Discussion of results}

Quality assurance is a priority of university institutions to achieve continuous improvement, so self-assessments are necessary, taking as a source of information the actors of the institutions and those who receive their services or impacts. Also, it becomes a priority to monitor your situation, obtaining direct information from those who receive the service (students). One of the highlights is to measure the level of satisfaction with the various quality indicators. As held by Pichardo et al. (2007), a student satisfied with the university institution confirms the quality of the university, since they are the same students who argue that they are satisfied to the extent that the services offered to them meet their needs.

The satisfaction indicators, with regard to the quality of the educational service, as well as the measurement of the academic quality of the implementation of the curriculums raised by Neumann, L. and Neumann, Y. (1985), include indicators consistent with what Ahmad and Almas proposed (2013).

Educ. Form., Fortaleza, v. 6, n. 3, e5293, set./dez. 2021

DOI: https://doi.org/10.25053/redufor.v6i2.5293

https://revistas.uece.br/index.php/redufor/index 
It is clear that knowledge and its application are increasing, Drucker (1993) defines this as the knowledge society. The need arises to generate spaces and mechanisms for updating the contents of the subjects, where teachers, professionals and entrepreneurs from the private, public, community sector, among others, can redefine the training needs that must be taken into account for the design of the Curriculum Plan and the programmatic contents of their subjects.

This study has carried out an evaluation of the expectation and perception of the educational service provided to students of the Faculty of Social Sciences and Humanities of the National University of Education Enrique Guzmán y Valle. They were applied the SERVQUAL survey of Parasuraman, Zeithaml and Berry (1988). In addition, these surveys have also been applied by Naldos and Rosas (2018) to students of the Service Management program at the University of Piura, noting that the perception of the security dimension has the highest average (5.7) not coincident with our results, which reflected a rating of 3.27. Meanwhile, the lower values have been relative to the responsiveness dimension, with an average of 4.52 , while our results were 4.13 . That is, the safety that officials have knowledge and their skills inspire confidence. As for the ability to respond, there is the lowest satisfaction assessment for the educational service, as they perceive that the willingness to help the student quickly does not meet the needs of the user.

As Ferreira and De Castro (2011) point out, the gap measures the difference between student satisfaction and the importance it attaches to the criterion to value. In this sense, when the gaps were compared, which mean the differences between perception and expectation of service, we note that the smallest gap is precisely the security dimension, coincidental with what is reported by Naldos and Rosas (2018).

Gaps found in the dimensions evaluated as tangibility, security, responsiveness, reliability and empathy range from -1.01 to -1.49 . According to Ferreira and De Castro (2011), the scores of the gaps between 0 and -1 do not exceed expectations, but there is a positive trend of perceiving that it goes towards quality. In this case, the results in all dimensions exceed those values, indicating greater gaps.

On the other hand, when we compare the perceptions of students of the Faculty of Social Sciences and Humanities of THE UNE, they are not coincident with Candelas et al. (2013), who found a high satisfaction value in the component of empathy $(68 \%)$, while in 
this study a valor less satisfaction (63\%) is observed, without achieving significant difference.

In addition, statistical tests to validate correlations, with respect to the expectations and perception of the educational service provided by UNE, have been determined that there is no correlation to the confidence level of 0.05 . This is consistent with what is reported by Neumann, L. and Neumann, Y. (1985), who suggest that student satisfaction information may be more useful in determining institutional organization levels than for individually evaluating the course or a member.

Rosas (1992) reports that the academic level can be defined in two perspectives. The first refers to the student, who defines it in terms of individual performance indicators; whether quantitative, such as notes, approved credits, study time, study satisfaction or as a degree achievement. The second refers to the university, which states that academic success has been operationalized in various ways such as the quality of applicants /students enrolled, origin of schools, or the academic quality of its prestige, publications, international recognition, among others. It has also been defined as academic success from a social macro perspective, based on the scientific, technological and cultural development achieved by the country in a certain time.

In this work we focus on determining the expectations of educational service in students and, also, their perception, this has allowed us to observe that Peruvian students tend to demand from a quality university with the same demand as other students such as Mexico which, according to Rosas (1992), are the needs of any university student.

From the analysis, it can be said that $62 \%$ of students perceive positively the quality of the service provided by the university, but the difference between importance and satisfaction requires implementing an improvement plan that makes it possible to meet the expectations of the student. The factors that are likely to affect student perception are job satisfaction and organizational commitment of teachers, as indicated by Araoz and Ramos (2021).

On the other hand, the SERVQUAL method was an appropriate tool for measuring the quality of educational service provided by a university. In addition, the results of this research can be seen as a document for management and decision-making as improvement plans are implemented, as strengths and weaknesses have been evident. Also, it is true that quality will depend on the customer who may have new needs over time; 
so their perception can change. Taking this into account, assessments of the quality of university service and its improvements should be a constant.

\section{References}

AHMAD, K.; ALMAS, A. A study of student's satisfaction in the University of the agriculture Faisalabad. International Journal of Intelligent Technologies and Applied Statistics, v. 6, n. 1, p. 21-34, 2013.

ARAOZ, E. G. E.; RAMOS, N. A. G. Satisfação no trabalho e compromisso organizacional em professores da Amazônia peruana. Educação e Formação, Fortaleza, v. 6, n. 1, p. e3854, 2021. Available at: https://revistas.uece.br/index.php/redufor/article/view/3854. Access on: Jan. 30 2021.

BULLÓN, S. R. La satisfacción estudiantil con la calidad educativa de la universidad. 2007. Tesis (Doctorado en Psicología) - Programa de Postgrado en Psicología, Pontificia Universidad Católica del Perú, Lima, 2007.

CANDELAS, C. et al. Medición de la satisfacción estudiantil universitaria: un estudio de caso en una institución mexicana. Iberoamerican Journal of Industrial Engineering, v. 5, n. 9, p. 261-274, 2013.

CORREIA, S. M.; MIRANDA, F. J. DUAQUAL: Calidad percibida por docentes y alumnos en la gestión universitaria. Management Letters Cuadernos de Gestión, v. 12, n. 1, p. 107-122, 2012.

DE CASTRO, V. et al. Dimensiones y determinantes de la satisfacción de alumnos en una institución de enseñanza superior. Revista Brasileira de Marketing, São Paulo, v. 1, n. 3, p. 193-220, 2012.

DRUCKER, P. F. La sociedad poscapitalista. Buenos Aires: Sudamericana. 1993.

FANTIN, M. Educação, aprendizagem e tecnologia na pesquisa-formação. Educação \& Formação, Fortaleza, v. 2, n. 3, p. 87-100, 2017. DOI 10.25053/edufor.v2i6.2377.

Available at: https://revistas.uece.br/index.php/redufor/article/view/161. Access on: June $25^{\text {th }}, 2020$.

FERREIRA, G. B.; DE CASTRO, S. Waldomiro. Avaliação da qualidade orientada ao usuário: estudo de caso em biblioteca acadêmica utilizando método SERVQUAL. Ciencias de la Información, La Habana, v. 42, n. 2, p. 55-59, 2011. 
FONSECA, G. R. As tecnologias de informação e comunicação na formação inicial de professores do $1^{\circ}$ ciclo do ensino básico - fatores constrangedores invocados pelos formadores para o uso das tecnologias. Educação \& Formação, Fortaleza, v. 4, n. 2, p. 3-23, 2019. DOI 10.25053/redufor.v4i11.254. Available at:

https://revistas.uece.br/index.php/redufor/article/view/254. Access on: May 15 ${ }^{\text {th }}, 2020$.

NALDOS, V.; ROSAS, S. Medición del cumplimiento de las expectativas de los alumnos de la Facultad de Ciencias Económicas y empresariales de la Universidad de Piura Campus Lima a través de la herramienta SERVQUAL. 2018. Tesis (Licenciatura en Administración de Servicios) - Programa de Administración de Servicios, Universidad de Piura, Lima, 2018.

NEUMANN, L.; NEUMANN, Y. Determinants of students' instructional evaluation: A comparison of four levels of academic areas. Journal of Educational Research, v. 78, n. 3, p.152-158, 1985.

PARASURAMAN, A.; ZEITHAML, V.; BERRY, L. SERVQUAL: a multiple-Item Scale for measuring consumer perceptions of service quality. Journal of Retailing, v. 64, n. 1, p. $12-40,1988$.

PERU. Decreto legislativo $N^{\circ} 1495$, de 10 de mayo de 2020. Lima: Congreso de la República, 2020a.

PERU. Decreto supremo Nº08-2020-AS, de 11 de marzo de 2020. Lima: Ministerio de Salud, 2020b.

PICHARDO, M. C. et al. El estudio de las expectativas en la universidad: análisis de trabajos empíricos y futuras líneas de investigación. Revista Electrónica de Investigación Educativa, Ensenada, v. 9, n. 1, p. 1-15, 2007.

ROSAS, R. Éxito académico universitario: problema de su definición, medición y predicción. Revista de la Escuela de Psicología de la Pontificia Universidad Católica de Chile, Santiago, v. 1, p. 25-39, 1992.

VERGARA, J. C.; QUESADA, V. M. Análisis de la calidad en el servicio y satisfacción de los estudiantes de Ciencias Económicas de la Universidad de Cartagena mediante un modelo de ecuaciones estructurales. Revista Electrónica de Investigación Educativa, Ensenada, v. 13, n. 1, p. 108-122, 2011.

YENQUE DE DIOS, J.; RÁEZ GUEVARA, L. Modelo de implementación de métodos modernos para mejorar la calidad de los servicios académicos administrativos en la Facultad de Ingeniería Industrial - U.N.M.S.M. Industrial Data, v. 2, n. 1, p. 21-28, 1999. 
Lidia Luz Cruz Neyra, Enrique Guzmán y Valle National University of Education

iDhttps://orcid.org/0000-0003-3902-4280

Doctor in Nutrition Sciences, with publications in national and international indexed journals. He has a specialization in university quality assessment. He has integrated various committees of external evaluators. He is currently a professor at the Enrique Guzmán y Valle National University of Education and the Ricardo Palma University.

Author contribution: Conception of the research and data collection.

E-mail: Icruz@une.edu.pe

Elías Saturnino Toledo Espinoza, Enrique Guzmán y Valle National University of Education, Academic Department of History and Geography

ii Dhttps://orcid.org/0000-0002-4625-4116

Doctor in Law and Political Sciences, with a master's degree in philosophy, educator and lawyer. He has published in national journals, has integrated the national commission in the formulation of educational research lines. He is currently a professor at the Enrique Guzmán y Valle National University of Education.

Author contribution: Methodological development and data collection.

E-mail: etoledo@une.edu.pe

Arturo Jaime Mendonza Ramírez, Enrique Guzmán y Valle National University of Education, Department of Psychology and Philosophy

iii https://orcid.org/0000-0002-7499-8497

Doctor of Educational Sciences, educator and lawyer, has a specialty in History. He has published various university and basic education texts and articles in national magazines. He is currently a professor at the Enrique Guzmán y Valle National University of Education.

Author contribution: Drafting of results and discussion.

E-mail: amendoza@une.edu.pe

Responsible publisher: Lia Machado Fiuza Fialho

Ad hoc experts: Carmen Claudio and João Vicente

How to cite this article (ABNT):

CRUZ NEYRA, Lidia Luz; TOLEDO ESPINOZA, Elías Saturnino; MENDONZA RAMÍREZ, Arturo Jaime. Quality of Educational Service at the Faculty of Social Sciences and Humanities of a Public University. Educ. Form., Fortaleza, v. 6, n. 3, e5293, 2021. Available at: https://revistas.uece.br/index.php/redufor/article/view/5293

Educ. Form., Fortaleza, v. 6, n. 3, e5293, set./dez. 2021

DOI: https://doi.org/10.25053/redufor.v6i2.5293

https://revistas.uece.br/index.php/redufor/index 


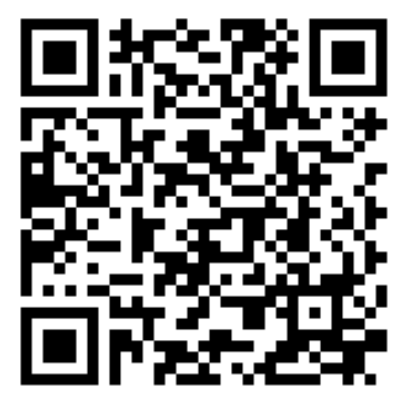

Received on March, 30"th 2021.

Accepted on April, 26 ${ }^{\text {th }}, 2021$.

Published on June, 28 ${ }^{\text {th }}, 2021$. 